Jurnal SEMANTIKA

Volume 1, No.01, Agustus 2019, p. 76-86

\title{
RITATOON UNTUK MENINGKATKAN KEMAMPUAN MENYIMAK PADA ANAK KELOMPOK B TK KHALIFA-IMS TEGAL
}

\author{
Nurchalistiani Budiana \\ Program Studi Pendidikan Bahasa dan Sastra Indonesia, Fakultas Keguruan dan Ilmu \\ Pendidikan, Universitas Muhadi Setiabudi Brebes, Indonesia \\ e-mail: chalistia@gmail.com
}

\begin{abstract}
ABSTRAK
Penelitian ini bertujuan untuk meningkatkan kemampuan menyimak anak melalui metode bercerita dengan media ritatoon pada anak kelompok B TK Khalifa-IMS Tegal. Penelitian ini dilakukan karena terdapat permasalahan di kelas terkait kemampuan menyimak di kelas B. Desain penelitian ini menggunakan Penelitian Tindakan Kelas (PTK) yang dilakukan secara kolaboratif dalam dua siklus. Subjek penelitian ini adalah anak kelompok $B$ TK Khalifa-IMS Tegal, dengan jumlah siswa sebanyak 15 anak. Metode pengumpulan data yang dilakukan adalah observasi dan dokumentasi. Teknik analisis data yang digunakan adalah deskriptif kuantitatif dan kualitatif. Kemampuan menyimak anak kelompok B di TK Khalifa-IMS Tegal dapat ditingkatkan melalui metode bercerita dengan media ritatoon. Tahap dalam proses menyimak yang dilakukan antara lain anak mendengarkan cerita yang disampaikan guru, anak mengerti dan memahami dengan baik isi cerita. Setelah anak memahami cerita, anak menginterpretasikan isi cerita dengan bercerita kembali, serta anak menanggapi pertanyaan yang diberikan guru. Guru memberi penguatan berupa reward kepada anak setelah anak bercerita kembali. Pada tahap pra tindakan persentase pencapaian kemampuan menyimak anak sebanyak $47,1 \%$ pada kriteria mulai berkembang (MB), kemudian meningkat pada siklus I menjadi 66,1\% berada pada kriteria berkembang sesuai harapan (BSH). Pada siklus II persentase pencapaian kemampuan menyimak anak meningkat menjadi 85\% pada kriteria berkembang sangat baik (BSB).
\end{abstract}

Kata Kunci: kemampuan menyimak, bercerita, ritatoon

\begin{abstract}
This study aims to improve the ability to listen to children through the method of storytelling with ritatoon media in children group B TK Khalifa-IMS Tegal. The design of this study used Classroom Action Research (CAR) which was conducted collaboratively in two cycles. The subjects of this study were children of group B TK Khalifa-IMS Tegal, with 15 students. Data collection methods used are observation and documentation. The data analysis technique used is descriptive quantitative and qualitative. The ability to listen to group B children in TK Khalifa-IMS Tegal can be improved through the method of storytelling with ritatoon media. The stages in the listening process include the child listening to the story told by the teacher, the child understanding and comprehending the contents of the story well. After the child understands the story, the child interprets the content of the story by telling the story again, as well as responding to questions given by the teacher. The teacher gives reinforcement in the form of reward to the child after the child tells the story again. In the pre-action stage, the percentage of attaining the ability to listen to children $47.1 \%$ in the criteria began to develop $(M B)$, then increased in the first cycle to $66.1 \%$ in the criteria for developing according to expectations (BSH). In cycle II, the percentage of children's listening ability increased to $85 \%$ on the very well developed criteria (BSB).
\end{abstract}

Keywords:: listening ability, telling stories, ritatoon

Submitted: 2019, Accepted: 2019, Published: Agustus 2019

ISSN: Xxxx-Xxxx (online), Website: http://jurnal.umus.ac.id/index.php/semantika 
Jurnal SEMANTIKA, Volume 1, No.01, Agustus 2019, p. 76-86

\section{PENDAHULUAN}

Anak usia dini merupakan anak pada rentang usia 0-6 tahun yang membutuhkan banyak stimulasi untuk membantu pertumbuhan dan perkembangan jasmani maupun rohaninya[1]. Pada usia ini, pemberian stimulasi dimaksudkan untuk mengoptimalkan berbagai aspek perkembangan anak yang meliputi perkembangan nilai-nilai agama dan moral, sosial emosional, bahasa, kognitif, fisik-motorik dan seni. Dari aspek-aspek perkembangan tersebut, bahasa merupakan suatu hal yang penting karena dengan bahasa anak dapat berkomunikasi dengan orang-orang di sekitarnya.

Menyimak merupakan kegiatan mendengarkan dengan penuh pemahaman dan perhatian serta apresiasi. Menyimak adalah suatu proses kegiatan mendengarkan lambang-lambang lisan dengan penuh perhatlan, pemahaman, apresiasi, serta interpretasi untuk memperoleh informasl, menangkap isi atau pesan, serta memahaml makna komunlkasl yang telah disampalkan sang pembicara melalui ujaran atau bahasa lisan [2].

Pentingnya menyimak dalam interaksi bahasa terutama komunikasi memang sangat nyata. Untuk terlibat dalam suatu komunikasi, seseorang harus memahami dan mereaksi apa yang baru saja dikatakan. Anak dapat memperoleh kosakata dan gramatikal serta pengucapan yang baik dengan kemampuan menyimak. Dengan demikian, kegiatan menyimak perlu dipusatkan dan dikembangkan sedini mungkin karena sebagai dasar pengembangan bahasa lainnya[3]. Pada usia Taman Kanak-kanak kemampuan anak masih terbatas dalam memahami bahasa dari pandangan orang lain. Akselarasi perkembangan bahasa anak terjadi sebagai hasil perkembangan simbolis. Jika pengembangan simbol bahasa telah berkembang, maka hal Inl memungkinkan anak belajar dari bahasa ucapan orang lain. Semakin banyak dan sering menyimak kosakata, pola kalimat, intonasi, dan sebagainya maka semakin berkembang pula keterampilan berbicara atau berbahasa anak.

Pada saat pembelajaran berlangsung, penggunaan metode bercerita belum secara optimal digunakan guru, dimana strategi dan teknik bercerita belum sesuai penerapannya. Selama ini guru dalam menyampaikan cerita, masih dalam bentuk metode ceramah sehingga anak terlihat bosan. Pembelajaran hanya berfokus pada aspek perkembangan yang lebih menitikberatkan pada aspek perkembangan kognitif dan motorik halus. Selain hal tersebut, penggunaan media yang ada belum digunakan secara optimal. Umumnya media digunakan anak untuk bermain-main ketika jam istirahat. Dalam kegiatan menyimak guru hanya menggunakan gambar yang ada di LKA sebagai media, belum terdapat media yang dapat digunakan sebagai alat bantu dalam bercerita. Hal ini membuat anak menjadi lebih memilih berbicara dengan teman sebangkunya daripada melihat gambar yang ada di LKA. Selain itu motivasi dari diri anak sendiri untuk melakukan kegiatan pembelajaran juga masih rendah.

Metode bercerita merupakan salah satu startegi pembelajaran yang dapat memberikan pengalaman belajar bagi anak. cerita yang disampalkan guru secara lisan harus menarik dan mengundang perhatian anak serta tidak lepas dari tujuan pendidikan Taman Kanak-kanak[4]. Apabila isi 
cerita dikaitkan dengan kehidupan anak sehari-hari, mereka akan mendengarkan dengan penuh perhatian dan dapat menangkap isi cerita dengan mudah. Selain itu, dapat menciptakan suasana yang menyenangkan.

$$
\text { Kegiatan bercerita dapat }
$$

dilakukan dengan berbagai media pembelajaran. Media pembelajaran mempunyai beberapa fungsi penting dalam kegiatan pembelajaran seperti memotivasi minat anak, menyajikan informasi, mengarahkan perhatian anak dan memperjelas penyampaian pesan. Dalam pelaksanaan proses pembelajaran, media pembelajaran sangat membantu dalam proses penyampaian materi atau informasi kepada anak dalam mencapai tujuan pembelajaran dan memudahkan siswa untuk memahami serta mengingat apa yang disampaikan guru. Dalam hal ini, bercerita dapat dilakukan dengan media pembelajaran sederhana dengan perangkat tiga dimensi salah satunya adalah dengan media gambar ritatoon.

Ritatoon merupakan gambar berseri yang dibingkai sedemikian rupa, tahapan-tahapan yang ditunjukkan pada gambar-gambar tersebut dapat dipresentasikan sebagai suatu proses kejadian[5]. Media ritatoon dapat disajikan dengan materi yang bisa disesuaikan sewaktu-waktu dengan bingkai tetap sehingga lebih ekonomis dan dapat digunakan disemua tingkat kelas. Dalam media ritatoon terdapat gambar dengan ukuran besar yang bisa didemonstrasikan di depan kelas dan bisa dilihat dengan jelas oleh seluruh anak dalam satu kelas. Perpaduan teks dan gambar dalam media ritatoon dapat menambah daya tarik serta dapat memperlancar pemahaman informasl yang disajikan dalam dua format yaitu verbal dan visual. Perangkat media ritatoon juga dapat digunakan untuk kegiatan lain selain bercerita sehingga penggunaan media ritatoon ini disesuaikan dengan tujuan pembelajaran. Bercerita dengan menggunakan media gambar ritatoon dapat membuat anak menjadi interaktif untuk melakukan interaksi dengan guru. Dengan adanya interaksi tersebut, maka kegiatan menylmak tidak akan monoton dan akan memudahkan anak untuk memahami isi cerita.

Berdasarkan latar belakang di atas rumusan masalah dalam penelitian ini, yaitu bagaimana meningkatkan kemampuan menyimak melalui media cerita ritatoon pada anak kelompok B di TK Khalifa-IMS Tegal? Tujuan dari penelitian ini memaparkan peningkatan kemampuan menyimak melalui media cerita ritatoon pada anak kelompok B di TK Khalifa-IMS Tegal.

\section{KAJIAN TEORI}

\section{a. Kemampuan bahasa anak usia} dini

Seseorang dapat dikatakan terampil berbahasa dengan baik, apabila orang itu mampu menguasai beberapa aspek dalam bahasa dengan sama baiknya. Ada beberapa karakteristik kemampuan bahasa anak usia 5-6 tahun, antara lain : (a) sudah dapat mengucapkan leblh darl 2.500 kosakata, (b) lingkup kosakata yang dapat diucapkan anak menyangkut: warna, ukuran, bentuk, rasa, bau, keindahan, kecepatan, suhu, perbedaan, perbandingan, jarak, permukaan (kasar-halus), (c) anak usia 5-6 tahun sudah dapat melakukan peran sebagai pendengar yang baik, (d) dapat berpartisipasi dalam suatu percakapan. Anak sudah dapat mendengarkan orang 
Jurnal SEMANTIKA, Volume 1, No.01, Agustus 2019, p. 76-86

lain berbicara dan menanggapi pembicaraan tersebut, (e) percakapan yang dilakukan oleh anak usia 5-6 tahun telah menyangkut berbagai komentarnya terhadap apa yang dilakukan oleh dirinya dan orang lain, serta apa yang dilihatnya. Anak pada usia 5-6 tahun sudah dapat melakukan ekspresi diri, menulis, membaca, dan bahkan berpuisi ${ }^{[6]}$.

\section{b. Kemampuan menyimak anak usia dini}

Menyimak adalah suatu proses kegiatan mendengarkan lambanglambang lisan dengan penuh perhatian, pemahaman, apresiasi, serta interpretasi untuk memperoleh informasi, menangkap isi atau pesan, serta memahami makna komunikasi yang telah disampaikan sang pembicara melalul ujaran atau bahasa lisan[2]. Mendengarkan dengan penuh perhatian berarti bahwa anak tidak hanya sekedar mendengarkan saja, la mendengarkan segala sesuatu yang dikemukakan oleh orang lain dengan penuh perhatian. Selain dengan penuh perhatian, proses kegiatan menyimak juga dilakukan dengan penuh pemahaman. Pemahaman ialah proses memahami suatu objek. Pemahaman dalam kegiatan menyimak merupakan proses memahami suatu bahan simakan[2].

Kemampuan menyimak anak diukur dari empat aturan secara fisik yang muncul ketika anak-anak melakukan keglatan menyimak, berikut penjelasannya dari terjemahan bahasa lnggrisnya : (a). Duduk tenang. Duduk tenang dalam hal ini adalah anak duduk di tempat duduknya dengan tidak berpindahpindah ke lantai. Pada saat anak duduk, anak terlihat duduk dengan sikap dan postur tubuh yang tepat sehingga anak lebih mudah fokus pada saat kegiatan menyimak dan memahami apa yang disampaikan oleh guru. (b). Melihat orang yang berbicara. Untuk menjadi penyimak dalam semua situasi perlu belajar bagaimana melakukan kontak mata dengan pembicara dalam setiap waktu pada saat mendengarkan pembicara. Hal ini dilakukan untuk membantu anak mendapatkan informasi yang lebih banyak tentang apa yang disampaikan pembicara. (c). Tetap tenang. Pada saat mendengarkan pembicara menyampaikan pesan dibutuhkan ketenangan agar penyimak dapat menerima informasi atau pesan dengan baik. Suasana yang tidak tenang akan berdampak lebih besar dalam kegiatan mendengarkan. Misalnya ketika anak sering berteriak, anak tidak hanya menganggu anak lain yang mendengarkan tetapi juga menganggu aktivitas pembicara.(d). Mendengarkan semua kata. Mendengarkan apa yang disampalkan oleh pembicara akan memudahkan penyimak untuk mengetahui isi pesan yang disampaikan pembicara sehingga ketika pembicara bertanya dan meminta penyimak untuk mengulangi pesan yang disampaikan, penyimak mampu menjawab dan mengulangi pesan tersebut[7].

Proses dalam kegiatan menyimak dilihat dari bagaimana fisik anak saat mendengarkan guru dalam menyampaikan cerita. Hal ini terlihat saat anak duduk mendengarkan cerita, anak akan duduk dengan sikap dan postur tubuh yang baik. Anak akan melakukan 
kontak mata dengan guru saat menyampaikan cerita sehingga anak mengetahui dan memahami apa yang dikatakan oleh guru. Untuk dapat mendengarkan dengan baik, diperlukan suasana yang tenang agar kegiatan menyimak tidak terganggu. Selaln itu, untuk dapat menangkap cerita yang disampalkan guru sebaiknya anak mendengarkan kata yang diucapkan guru dan memahami makna komunikasi yang disampaikan melalui bahasa lisan.

c. Ritatoon Media Bercerita Untuk Meningkatkan Kemampuan Menyimak Anak TK

Pembelalaran di Taman Kanakkanak pada umumnya menggunakan pendekatan tematik karena pembelajaran akan lebih bermakna untuk anak[8].

Pembelajaran dengan pendekatan tematik mencakup tiga tahap yang berurutan, yaitu: 1) perencanaan atau persiapan; 2) pelaksanaan; 3) evaluasi[9].

\section{METODE PENELITIAN}

Jenis penelitian yang digunakan dalam penelitian ini adalah penelitian tindakan kelas atau Classroom Action Research. Penelitian tindakan kelas merupakan suatu pencermatan terhadap kegiatan yang akar permasalahannya muncul di kelas dengan tujuan untuk memperbaiki proses pembelajaran di kelas[10].

Desain penelitian ini merupakan pengembangan model Kurt Lewin. Model ini mencakup empat komponen yaitu perencanaan, tindakan, pengamatan dan refleksi. Akan tetapi komponen tindakan dan pengamatan dijadikan satu komponen karena kedua kegiatan tersebut merupakan dua kegiatan yang tidak terpisahkan[11]

Subjek dalam penelitian ini adalah anak-anak kelompok B di TK Khalifa IMS Tegal dengan jumlah 15 anak yang terdiri darl 6 siswa laki-laki dan 9 siswa perempuan. Data yang terkumpul dalam penelitian ini akan dianalisis menggunakan teknik deskriptif kualitatif dan deskriptif kuantitatif. Analisis data kualitatif digunakan untuk menentukan peningkatan proses belajar khususnya berbagai tindakan yang dilakukan guru, sedangkan analisis data kuantitatif digunakan untuk menentukan peningkatan hasil belajar siswa dari setiap tindakan yang dilakukan guru[12]

Data kualitatif dalam penelitian ini adalah data yang merujuk pada kualitas objek yang diteliti, yaitu kemampuan menyimak dalam kegiatan bercerita dengan media ritatoon. Untuk menentukan peningkatan hasil belajar siswa sebagai pengaruh dari setiap tindakan yang dilakukan guru, digunakan analisis data kuantitatif. Rumus perhitungan persentase yang digunakan untuk mengetahui peningkatan kemampuan menyimak anak dalam kegiatan bercerita dengan media ritatoon.

Adapun rumus yang digunakan peneliti untuk mengetahul persentase pencapaian keberhasilan kemampuan menyimak anak dalam penelitian ini menggunakan rumus ${ }^{[13]}$

Persentase $=\frac{\text { Skor keseluruhan yang diperoleh anak }}{\text { Jumlah anak x skor maksimum }} \times 100 \%$

Dari hasil perhitungan rumus di atas, hasil yang diperoleh selanjutnya diinterpretasikan ke dalam empat kriteria persentase kemudian dimodifikasi oleh peneliti. Berikut kriteria interpretasinya: 
Jurnal SEMANTIKA, Volume 1, No.01, Agustus 2019, p. 76-86

Tabel 1. Kriteria penilaian kemampuan menyimak anak

\begin{tabular}{|c|c|c|}
\hline No. & Persentase & Kriteria \\
\hline 1 & $80 \%-100 \%$ & Berkembang Sangat Baik \\
\hline 2 & $60 \%-79 \%$ & Berkembang Sesuai Harapan \\
\hline 3 & $30 \%-59 \%$ & Mulai Berkembang \\
\hline 4 & $0 \%-29 \%$ & Belum Berkembang \\
\hline
\end{tabular}

\section{HASIL DAN PEMBAHASAN}

Hasil

\section{Pelaksanaan siklus I}

\section{a. Perencanaan}

Dari hasil observasi yang diperoleh saat pratindakan, peneliti dan guru menyusun rencana pelaksanaan tindakan pada siklus I dengan memberikan tindakan bercerita kepada anak dengan media ritatoon dalam kegiatan menyimak. Pelaksanaan tindakan pada siklus I ini dilaksanakan selama tiga kali pertemuan

b. Pelaksanaan Tindakan

1). Siklus I Pertemuan I : a). Kegiatan awal. Bel masuk berbunyi pada pukul 07.30, siswa berbaris di halaman sekolah. Salah satu anak memimpin untuk menyiapkan barisan kemudian kembali masuk ke barisan. Siswa melakukan senam irama yang dipimpin oleh guru dilanjut dengan menyanyi lagu "Loneeng Berbunyi" dan anak-anak masuk ke kelas. Pada kegiatan awal ini, di dalam kelas guru mengajak anak untuk berdoa bersama, menyanyi, dan melakukan ice breaking. Sebelum guru memulai kegiatan, guru melakukan presensi untuk mengetahui jumlah anak yang berangkat dan tidak. Kemudian guru melakukan apersepsi kepada anak. Apersepsi dilakukan dengan memberikan pertanyaan yang berhubungan dengan pengalaman sehari-hari dan dikaitkan dengan tema pembelajaran yaitu "Alam Semesta" dengan sub tema "Gejala Alam/Banjir". Anakanak menyampaikan apa yang mereka ketahui tentang banjir. Selanjutnya guru menjelaskan kegiatan yang akan dilakukan pada hari itu. b). Kegiatan inti. Kegiatan bercerita dimulai dengan guru menggali pengalaman anak dan mengkaitkannya dengan tema cerita dalam pembelajaran. Anak-anak mengutarakan pendapat yang berbeda-beda mengenai tema cerita yang akan dibacakan guru. Kemudian guru membacakan judul cerita berkali-kali dan meminta anak untuk mengulanginya. Hal tersebut dilakukan agar anak-anak mengingat judul cerita tersebut. Guru membacakan cerita dengan suara yang keras agar semua anak dapat mendengarnya. Di sela-sela bercerita, guru memberikan beberapa pertanyaan terkait dengan isi cerita dan mengaitkannya dengan pengalaman anak. Cara guru menggunakan media ritatoon dalam bercerita adalah dengan mengambil bingkai gambar satu persatu dari yang paling depan kemudian apabila sudah selesai bingkai gambar diletakkan di bawah, begitu seterusnya untuk cerita selanjutnya.

c. Kegiatan Penutup. Anak-anak mencuci tangan kemudian bersiap makan bekal bersama. Setelah selesai makan bersama, guru melakukan recalling kegiatan yang sudah dilakukan pada hari itu. Guru memberikan pertanyaan kepada anak mengenai kegiatan yang telah dilakukan hari itu. Kemudian anak-anak membereskan alat tulisnya dan bersiap untuk berdoa 
sebelum pulang. Sebelum mengucapkan salam, guru memberikan pesan kepada anakanak mengenai hal-hal yang harus dilakukan ketika dan setelah pulang sekolah. Setelah itu guru mengucapkan salam dan satu persatu anak menutup gambar pada papan presensi, berjabat tangan dengan guru, lalu pulang.

\section{Pelaksanaan siklus II}

a. Kegiatan awal.

Bel masuk berbunyi pada pukul 07.30, siswa berbaris dihalaman sekolah. Salah satu anak memimpin untuk menyiapkan barisan kemudian kembali masuk ke barisan. Siswa melakukan senam irama yang dipimpin oleh guru dilanjut dengan menyanyi lagu "Lonceng Berbunyi" dan anakanak masuk ke kelas. Pada kegiatan awal ini, di dalam kelas guru mengajak anak untuk berdoa bersama, menyanyi, dan melakukan ice breaking. Sebelum guru memulai kegiatan, guru melakukan presensi untuk mengetahui jumlah anak yang berangkat dan tidak. Kemudian guru melakukan apersepsi kepada anak. Apersepsi dilakukan dengan memberikan pertanyaan yang berhubungan dengan pengalaman sehari-hari dan dikaitkan dengan tema pembelajaran yaitu "Alam Semesta" dengan sub tema "Benda-benda

Langit/Matahari". Anak-anak menyampaikan apa yang mereka ketahui tentang matahari. Selanjutnya guru menjelaskan kegiatan yang akan dilakukan pada hari itu. b. Kegiatan inti.

Kegiatan bercerita dimulai dengan guru menggali pengalaman anak dan mengkaitkannya dengan tema cerita dalam pembelajaran.Anakanak mengutarakan pendapat yang berbeda-beda mengenai tema cerita yang akan dibacakan guru. Kemudian guru membacakan judul cerita berkali-kali dan meminta anak untuk mengulanginya.

c. Kegiatan penutup.

Anak-anak mencuci tangan kemudian bersiap makan bekal bersama. Setelah selesai makan bersama, guru melakukan recalling kegiatan yang sudah dilakukan. Guru memberikan pertanyaan kepada anak mengenai kegiatan yang telah dilakukan hari itu. Kemudian anak-anak membereskan alat tulisnya dan bersiap untuk berdoa sebelum pulang dilanjut dengan menyanyikan lagu "Hari Ini". Sebelum mengucapkan salam, guru memberikan pesan kepada anak-anak mengenai hal-hal yang harus dilakukan ketika dan setelah pulang sekolah. Setelah itu guru mengucapkan salam dan satu persatu anak menutup gambar pada papan presensi, berjabat tangan dengan guru, lalu pulang.

\section{Pembahasan}

Penelitian yang dilakukan ini merupakan penelitian tindakan kelas yang dilakukan dalam dua siklus. Setiap siklus terdiri dari perencanaan, tindakan \& observasi, refleksi. Hasil yang diperoleh dalam penelitian ini berupa hasil dari tindakan yang diberikan peneliti untuk meningkatkan kemampuan menyimak anak. Kemampuan menyimak kelompok B di 
TK Khalifa - IMS Tegal mengalami peningkatan pada setiap indikator dan setiap siklusnya.

Pada indikator pertama yaitu duduk tenang, pencapaian persentase pada saat pra tindakan sebanyak $46,7 \%$, kemudian meningkat pada siklus 1 menjadi $68,9 \%$, kemudian meningkat lagi menjadi $87,8 \%$ pada siklus II. Pada pra tindakan, ketika mendengarkan cerita, anak terkadang berdiri dari tempat duduknya, bahkan ada yang berpindah ke lantai. Ada anak yang bertahan duduk tetapi sambil memainkan sesuatu yang ada dimejanya. Anak juga duduk dengan sikap dan postur tubuh yang tidak sesuai. Pada siklus 1, perilaku yang nampak pada anak saat mendengarkan cerita yaitu, anak bertahan duduk dengan sikap dan postur tubuh yang sesuai tetapi tidak bertahan lama dan anak bertahan duduk meskipun masih meletakkan kepala di atas meja. Pada siklus 11, perilaku anak mengalami peningkatan yaitu anak terlihat memperhatikan guru dan gambar cerita serta anak duduk dengan sikap dan postur tubuh yang sesuai, meskipun masih terdapat anak yang terkadang gelisah saat mendengarkan cerita.

Pada indikator kedua yaitu melihat orang yang berbicara, pencapaian persentase pada saat pra tindakan sebanyak $48,3 \%$, kemudian meningkat pada siklus 1 menjadi $64,4 \%$, kemudian meningkat lagi menjadi $85,6 \%$ pada siklus 11. Pada pra tindakan, saat guru menyampaikancerita, anak belum melihat guru ketika bercerita dengan baik. Anak melihat guru hanya sepintas tidak terus-menerus dan mau melihat guru setelah ditegur. Pada siklus 1, sudah ada anak yang mau melihat guru ketika bercerita dan masih juga terdapat anak yang membagi pandangannya dengan melihat keluar kelas atau melihat temannya. Pada siklus 11, perilaku anak saat guru menyampaikan cerita, anak terlihat sudah mau melihat guru yang bercerita meskipun tidak terus-menerus dan mau melihat guru setelah diingatkan.

Pada indikator ketiga yaitu tetap tenang, pencapaian persentase pada saat pra tindakan sebanyak 50\%, kemudian meningkat pada siklus 1 menjadi $67,2 \%$, kemudian meningkat lagi menjadi $85 \%$ pada siklus 11. Pada pra tindakan, saat kegiatan bercerita, anak masih belum bisa tenang. Ketika guru bercerita, ada anak yang masih berbicara sendiri dengan teman sebangkunya dan menyela pembicaraan guru ketika berbicara. Pada siklus 1, anak masih terlihat belum tenang. Anak kadang berbicara tetapi anak bisa diingatkan guru untuk tetap tenang dan kembali mendengarkan meskipun guru harus memberi jeda ketika suasana tidak tenang. Pada siklus 11, anak terlihat bisa dikondisikan untuk tenang dan mendengarkan cerita yang disampaikan guru meskipun masih ada satu anak yang belum bertahan lama untuk tetap tenang.

Pada indikator keempat yaitu mendengarkan semua kata, pencapaian persentase pada saat pra tindakan sebanyak 43,3\%, kemudian meningkat pada siklus 1 menjadi $63,9 \%$, kemudian meningkat lagi menjadi $81,7 \%$ pada siklus 11. Pada pra tindakan, hanya ada satu anak yang mau bercerita kembali dan menggunakan kata-kata dasar. Selain itu, juga terdapat 1 anak yang mengalami keterlambatan berbicara sehingga pada saat kegiatan menyimak ketika guru memberi pertanyaan atau meminta untuk bercerita kembali, guru susah dalam memahami kata yang diucapkan anak.

Salah satu faktor yang mempengaruhi menyimak adalah fisik dan sikap anak[2]. Pada siklus 1, anak mulai mau bercerita dengan bantuan guru dan anak menjawab pertanyaan 
Jurnal SEMANTIKA, Volume 1, No.01, Agustus 2019, p. 76-86

maupun bercerita kembali dengan satu sampai dua kata saja. Cerita yang diungkapkan anak sudah mulai runtut. Pada siklus 11, terlihat anak antusias untuk menjawab pertanyaan ketika guru memberi pertanyaan kepada anak. Anak tanpa ditunjuk, sudah mengajukan dirinya untuk bercerita kembali di depan kelas. Ada 14 anak yang mau menceritakan kembali cerita yang disampaikan guru. Ada 5 anak yang bercerita kembali secara runtut dan menggunakan kata-kata yang sesuai dengan isi cerita.

Rata-rata pencapaian kemampuan menyimak kelompok B di TK Khalifa IMS Tegal mengalami peningkatan pada setiap siklusnya. Pada pra tindakan, rata-rata pencapaian yang dicapai sebanyak 47,1\%, kemudian meningkat pada siklus 1 menjadi 66, $1 \%$, kemudian meningkat lagi menjadi $85 \%$ pada siklus 11 dan berada pada kriteria BSB. Pada siklus 11 ini, kemampuan menyimak anak sudah mencapai indikator keberhasilan yang ditentukan oleh peneliti. Hasil tersebut sudah mencapai indikator keberhasilan yang telah direncanakan peneliti dimana minimal $80 \%$ dari jumlah anak mencapai kriteria kemampuan menyimak dengan kriteria BSB.

Peningkatan kemampuan menyimak anak terlihat pada saat guru ingin bercerita, anak sudah mengerti apa apa yang harus dilakukan yaitu duduk tenang mendengarkan guru, kemudian saat guru memberi pertanyaan, anak menjawab dengan tepat tanpa meniru anak lain, saat diminta untuk bercerita kembali, anak berani maju ke depan untuk bercerita kembali dengan runtut dan menggunakan kata-kata yang tepat. Anak menunjukkan semangat yang lebih saat memahami cerita dan menyampaikan kembali tentang cerita ketika guru memotiyasi anak dengan memberikan reward.
Berdasarkan hasil yang dicapai pada tindakan siklus 1 dan 11 , dapat ditegaskan bahwa peningkatan kemampuan menyimak anak dapat ditingkatkan dengan metode bercerita salah satunya dengan strategi penceritaan kembali ereproduksi). Beberapa strategi dalam menyampaikan cerita salah satunya dengan strategi penceritaan kembali[15].

Strategi penceritaan kembali adalah kegiatan anak setelah memahami cerita dan kemudian menceritakan kembali isi cerita. Dari hasil observasi juga terlihat bahwa dengan kegiatan menyimak membantu anak untuk membayangkan tentang apa yang didengarnya sehingga pada saat guru menyampaikan cerita anak bertanya tentang cerita yang dikaitkan dengan kehidupan anak sehari-hari. Manfaat cerita salah satunya adalah cerita dapat menyalurkan imajinasi anak. Pada saat anak menyimak cerita, imajinasi anak dirangsang. Anak akan membayangkan cerita yang didengarnya melalui imajinasi. lmajinasi yang dibangun anak saat menyimak cerita memberikan pengaruh positif[16].

Peneliti menggunakan media pembelajaran berupa media ritatoon dalam kegiatan menyimak pada setiap siklusnya. Hasil yang dicapai dalam penggunaan media ritatoon ini terbukti dapat meningkatkan kemampuan menyimak anak. Karena dengan media pembelajaran ini, kegiatan pembelajaran menjadi lebih jelas dan mengarahkan perhatian anak sehingga menimbulkan motiyasi belajar yang tinggi.

Berdasarkan data hasil penelitian, kemampuan menyimak setiap anak mengalami peningkatan secara bertahap pada tiap siklusnya. Hasil tersebut menegaskan bahwa metode bercerita dengan media ritatoon dapat dijadikan salah satu alternatif bagi guru untuk 
menstimulasi kemampuan menyimak anak didiknya.

\section{KESIMPULAN DAN SARAN Kesimpulan}

Kemampuan menyimak anak kelompok B di TK Khalifa dapat ditingkatkan melalui metode bercerita dengan media ritatoon. Langkah-langkah dalam proses menyimak yang dilakukan antara lain anak mendengarkan cerita yang disampaikan guru, anak mengerti dan memahami dengan baik isi cerita.

Setelah anak memahami cerita, anak menginterpretasikan dan mengevaluasi penyampaian guru terhadap cerita dengan anak bercerita kembali tentang isi cerita, serta anak menanggapi pertanyaan yang diberikan guru. Guru memberi penguatan berupa reward kepada anak setelah anak bercerita kembali, hal ini dilakukan untuk memotivasi anak dalam menyimak cerita.

Peningkatan kemampuan menyimak terjadi pada setiap siklus dan meningkat dengan baik. Pada tahap pra tindakan persentase pencapaian kemampuan menyimak anak sebanyak $47,1 \%$ berada pada kriteria mulai berkembang (MB), kemudian meningkat pada siklus I menjadi $66,1 \%$ berada pada kriteria berkembang sesuai harapan (BSH). Pada siklus II persentase pencapaian kemampuan menyimak anak meningkat mencapai $85 \%$ berada pada kriteria berkembang sangat baik (BSB).

\section{Saran}

Berdasarkan kesimpulan penelitian ini disarankan sebagai berikut:

1. Memfokuskan kegiatan bercerita hanya pada penceritaan kembali sehingga anak dapat dengan mudah mengungkapkan apa yang disimaknya.

2. Menggunakan cerita bergambar dengan ukuran besar dan berwarna agar anak lebih tertarik serta membantu anak mengingat alur cerita.

3. Menghindari kegiatan menyimak setelah anak melakukan aktivitas fisik- motorik yang berat misalnya senam dan jalan sehat, sehingga pada saat kegiatan menyimak fokus anak tidak berkurang karena kelelahan.

\section{DAFTAR PUSTAKA}

[1] Undang-Undang Republik Indonesia Nomor 20 Tahun 2003 tentang Sistem pendidikan Nasional. Jakarta: Kementrian Pendidikan Nasional.

[2] Tarigan, H.G., 2008, Menyimak Sebagai Suatu Keterampilan Berbahasa. Bandung: Angkasa.

[3] Azies \& Alwasih, 2000, Pengajaran Bahasa Komunikatif, Bandung: PT.Remaja Rosdakarya.

[4] Masitoh, 2006, Strategi Pembelajaran TK, Jakarta: Universitas Terbuka

[5] Prasetyo, E. B., 2000, Media Sederhana dan Grafis, Yogyakarta: FIP UNY.

[6] Jamaris, M., 2006, Perkembangan dan Pengembangan Anak Usia Taman Kanak-kanak Pedoman bagi Orangtua dan Guru, Jakarta: PT Gramedia Widiasarana Indonesia.

[7] Spooner, Liz \& Jacqui, Woodcock, 2010, Teaching Children To Listen A Practical Approach To Developing Children's Listening Skill's. New York: MPG Books Group. 
[8] Dhieni, N., dkk., 2005, Metode Pengembangan Bahasa, Jakarta: Universitas Terbuka.

[9] Mamat S., dkk. 2005. Pedoman Pelaksanaan Pembelajaran Tematik. Jakarta: Departemen Agama RI.

[10] Arikunto, S., Suhardjono \& Supardi., 2015, Penelitian Tindakan Kelas, Jakarta: Bumi Aksara.

[11] Kusumah, W., Dwitagama, D., 2010, Mengenal Penelitian Tindakan Kelas. Jakarta: PT indeks.

[12] Sanjaya, W., 2011, Penelitian Tindakan Kelas, Jakarta: Kencana Prenada Media Group.

[13] Yoni, A., dkk., 2010, Menyusun Penelitian Tindakan Kelas, Yogyakarta: Familia.

[14]. Sudijono, A., 2010, Pengantar Statistik Pendidikan. Jakarta: Rajawali Press.

[15] Mustakim. M. N., 2005, Peranan Cerita dalam Pembentukan Perkembangan Anak TK, Jakarta: Departemen Pendidikan Nasional, Direktorat Jenderal Perguruan Tinggi, Direktorat Pembinaan Pendidikan Tenaga Kependidikan dan Ketenagaan Perguruan Tinggi

[16] Tadkiroatu, Musfiroh., 2005, Bermain Sambil Belajar dan Mengasah Kecerdasan. Jakarta. Depdiknas 